Introduction to

ELECTRICAL MACHINES 
Other Titles in Electrical and Electronic Engineering

G. B. Clayton: Experiments with Operational Amplifiers

G. B. Clayton: Linear Integrated Circuit Applications

J. C. Cluley: Electronic Equipment Reliability

R. F. W. Coates: Modern Communication Systems

C. W. Davidson: Transmission Lines for Communications

W. Gosling: A First Course in Applied Electronics

B. A. Gregory: An Introduction to Electrical Instrumentation

Paul A. Lynn: An Introduction to the Analysis and Processing of Signals

A. G. Martin and F. W. Stephenson: Linear Microelectronic Systems

R. G. Meadows: Electrical Communications-Theory, worked examples and problems

J. E. Parton and S. J. T. Owen: Applied Electromagnetics

A. Potton: An Introduction to Digital Logic

J. T. Wallmark and L. G. Carlstedt: Field-effect Transistors in Integrated Circuits

G. Williams: An Introduction to Electrical Circuit Theory 


\section{Introduction to \\ ELECTRICAL \\ MACHINES}

A. R. Daniels

University of Bath

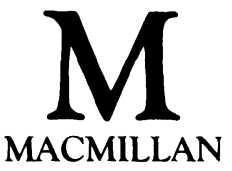


(C) A. R. Daniels 1976

All rights reserved. No reproduction, copy or transmission of this publication may be made without written permission.

No paragraph of this publication may be reproduced, copied or transmitted save with written permission or in accordance with the provisions of the Copyright Act 1956 (as amended).

Any person who does any unauthorised act in relation to this publication may be liable to criminal prosecution and civil claims for damages.

First published 1976

Reprinted 1978, 1979, 1982, 1985

Published by

Higher and Further Education Division

MACMILLAN PUBLISHERS LTD

Houndmills, Basingstoke, Hampshire RG21 2XS

and London

Companies and representatives

throughout the world

ISBN 978-0-333-19627-4

ISBN 978-1-349-15689-4 (eBook)

DOI 10.1007/978-1-349-15689-4 


\section{Contents}

Preface viii

1 The Basis of Operation of Electromagnetic Machines 1

1.1 Basic elements 1

1.2 Production of a rotating m.m.f. 4

$\begin{array}{lll}1.3 & \text { The general machine } & 6\end{array}$

1.4 Particular cases of the general machine 8

$\begin{array}{ll}1.5 \text { Circuit conventions } & 15\end{array}$

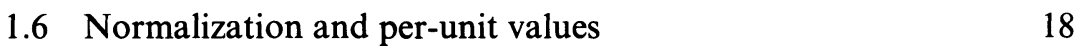

2 Armature Winding Arrangements 20

$\begin{array}{lll}2.1 & \text { Polyphase winding arrangements } & 21\end{array}$

2.2 D.C. machine armature windings 25

$\begin{array}{ll}\text { Tutorial problems } & 29\end{array}$

3 Process of Energy Conversion 30

3.1 Electromechanical energy conversion 30

$\begin{array}{ll}3.2 \text { Generation of e.m.f. } & 38\end{array}$

3.3 Winding factors for a.c. machine windings 39

3.4 Production of torque $\quad 40$

Tutorial problems $\quad 42$

4 The Transformer 43

4.1 The ideal single-phase transformer 43

4.2 The practical single-phase transformer 45

4.3 Derivation of equivalent circuits 48

4.4 Determination of transformer parameters 50

4.5 Performance calculations 53

4.6 Voltage regulation $\quad 55$

$\begin{array}{lll}4.7 & \text { Efficiency } & 56\end{array}$

4.8 Parallel operation 58

4.9 The waveform of no-load current 61 
4.10 3-Phase transformer connections 66

4.11 Parallel operation of 3-phase transformers 70

$\begin{array}{ll}4.12 \text { The auto-transformer } & 70\end{array}$

$\begin{array}{ll}\text { Tutorial problems } & 71\end{array}$

5 Polyphase Induction Motors $\quad 74$

$\begin{array}{lll}5.1 & \text { Derivation of equivalent circuits } & 74\end{array}$

5.2 Power balance equations $\quad 77$

$\begin{array}{lll}5.3 & \text { Torque calculations } & 78\end{array}$

$\begin{array}{lll}5.4 & \text { Output power calculations } & 81\end{array}$

5.5 Determination of circuit parameters $\quad 84$

5.6 Starting methods for induction motors 87

5.7 Speed control of induction motors 90

5.8 Dynamic operation of induction motors 97

$\begin{array}{ll}\text { Reference } & 98\end{array}$

$\begin{array}{ll}\text { Tutorial problems } & 99\end{array}$

6 Single-phase Motors 101

6.1 The single-phase induction motor 101

$\begin{array}{ll}\text { 6.2 Locus diagrams for single-phase motors } & 106\end{array}$

$\begin{array}{lll}6.3 & \text { The shaded-pole motor } & 108\end{array}$

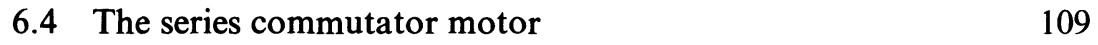

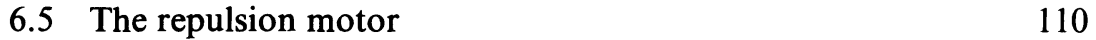

$\begin{array}{ll}\text { Reference } & 111\end{array}$

$\begin{array}{ll}\text { Tutorial problems } & 111\end{array}$

7 The Polyphase Synchronous Machine 113

7.1 Basis of operation of cylindrical rotor machines 113

$\begin{array}{lll}7.2 & \text { Equivalent circuits for cylindrical rotor machines } & 116\end{array}$

$\begin{array}{lll}7.3 & \text { Open-circuit and short-circuit characteristics } & 118\end{array}$

$\begin{array}{lll}7.4 & \text { Basis of operation of salient pole machines } & 120\end{array}$

$\begin{array}{ll}7.5 & \text { Determination of synchronous reactances } \\ 7.6 & 122\end{array}$

$\begin{array}{lll}7.6 & \text { Voltage regulation of generators } & 123\end{array}$

$\begin{array}{lll}7.7 & \text { Paralleling of polyphase synchronous machines } & 124\end{array}$

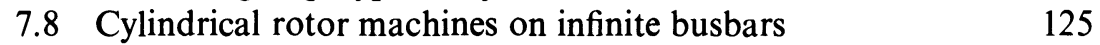

$\begin{array}{ll}\text { 7.9 Salient pole machines on infinite busbars } & 129\end{array}$

$\begin{array}{ll}7.10 \text { Parallel operation of generators } & 130\end{array}$



7.12 Starting of synchronous motors 134

$\begin{array}{lr}\text { References } & 135\end{array}$

$\begin{array}{ll}\text { Tutorial problems } & 135\end{array}$ 
8.1 Armature reaction 137

8.2 The commutation process 139

8.3 Generator performance characteristics 141

8.4 The separately excited generator 142

8.5 The shunt generator 143

8.6 Performance characteristics of motors 145

8.7 The shunt motor 146

$\begin{array}{lll}8.8 & \text { The series motor } & 147\end{array}$

8.9 The compound motor 151

8.10 Speed control of motors 151

8.11 The Ward-Leonard method of speed control 152

8.12 Motor starters 153

8.13 Losses and efficiency 154

8.14 Dynamics of separately excited motors 156

$\begin{array}{ll}\text { Tutorial problems } & 160\end{array}$

9 Semiconductor Control of Motors 164

9.1 The thyristor as a power device 164

9.2 Thyristor firing mechanisms 165

$\begin{array}{ll}9.3 \text { Gate firing } & 167\end{array}$

$\begin{array}{lll}9.4 & \text { Series and parallel operation } & 169\end{array}$

9.5 Overcurrent protection 171

9.6 Natural commutation 172

$\begin{array}{lll}9.7 \text { Forced commutation } & 176\end{array}$

9.8 Speed control of d.c. motors 177

9.9 Speed control of a.c. motors 181

References 184

$\begin{array}{ll}\text { Index } & 185\end{array}$ 


\section{Preface}

The attention given to the study of the performance of electrical machines has, in recent years, been reduced in many higher-education courses. Developments have taken place which, in the early stages, emphasize the similarities, rather than the differences, between the various machine types. In preparing this text, a basic approach to the formation of operating equations has been made using the concept of a so-called 'general machine' whose operation covers all the well-established different machine types. In this manner, the concepts of synchronous and asynchronous operation and the action of both a.c. and d.c. commutator motors are introduced at the earliest possible stage. Since the action of all electrical machines depends on energy storage in a coupling field, a simplified treatment of electromechanical energy conversion has been included.

Once the common principles governing the operation of all forms of electrical machine have been established, each different machine type is dealt with separately in a conventional manner. Modern teaching courses take place at a rapid pace and the salient facts in the basic analysis of each machine type are considered first in each chapter. In this way, more advanced topics in certain chapters can be omitted without disrupting the continuity of the text. The first section of the book (chapters 1-3) considers general principles and also deals with winding arrangements. The performance of the transformer and the various machine types is considered in the next section (chapters 4-8) and the final section (chapter 9) deals with the characteristics and application of the power thyristor when used to control the speed of both d.c. and a.c. motors.

Throughout the text, distinction between phasor and scalor quantities is made by the use of bold type to designate phasors. In the particular case of phasor diagrams which, in any case, always depict phasors, bold type is not used. A simple circuit convention for a source of energy (generator) and for a sink of energy (motor) is used throughout the text. This particular convention is only one of many possible conventions and its only requirement is that it should be correctly and continuously applied.

I would like to thank the Council of the University of Bath for permission to use past examination papers. Any dedication made must be to my past students, all of whom survived after treatment with the material contained in this textbook. 